\title{
Investigation of the Factors Affecting the Sexual Function in Women of Reproductive Age Referred to the Women's Clinic of Hakim Neyshabur Hospital in 2015, Iran
}

\author{
Fatemeh Shamsabadi ${ }^{1}$, Zahra Kamali ${ }^{2}$, Mahboobeh Gholami ${ }^{3}$, Toktam Bayat ${ }^{1}$, Akram Poosti $^{4}$, \\ Marzeiyeh Feizi ${ }^{5}$ \\ ${ }^{1}$ Student Research Committee, Neyshabur University of Medical Sciences, Neyshabur, Iran \\ ${ }^{2}$ Department of Midwifery, School of Nursing and Midwifery, Mashhad University of Medical Sciences, \\ Mashhad, Iran \\ ${ }^{3} \mathrm{PhD}$ in Clinical Sciences, Department of Midwifery, Neyshabur University of Medical Sciences, Neyshabur, Iran \\ ${ }^{4}$ Neyshabur University of Medical Sciences, Neyshabur, Iran \\ ${ }^{5}$ Clinical Psychologist, Neyshabur University of Medical Sciences, Neyshabur, Iran
}

\section{SUMMARY}

The aim of this study was to determine the factors affecting the sexual function of women of reproductive age with reference to the adverse effects of sexual dysfunction in women and its consequences on family life.

This research was a cross-sectional study conducted in 2014-2015 and the study population included married women with stable sexual activities (at least for the last four weeks) referred to Women's Clinics of Hakim Neyshabur Hospital, Iran. The criteria for this study were as follows: being at the fertility age, being married and having regular sexual activity during the last four weeks. The study also included the women with a history of vaginal surgery, uterine surgery, vaginal or uterine anomalies, mental illness, any use of psychoactive or narcotic drugs. A standard questionnaire for women's sexual function (FSFI) was used for data collection. Data were analyzed using SPSS16 software, chi-square test, and one-way analysis of variance.

The findings showed that the prevalence of sexual dysfunction was significantly related to the level of education, husband's employment status, family income, specific diseases, and husband's education $(p<0.05)$. Moreover, the highest prevalence was found for orgasmic disorder, lubrication disorder, libido disorder, stimulation disorder, and sexual dysfunction.

Sexual abnormalities are highly prevalent in women of reproductive age, and the establishment of counseling and educational centers to identify these women and their needs seem to be necessary. 
Original article

Key words: sexual dysfunction, women's sexual function index, orgasm, lubrication, sexual desire, sexual stimulation, pain during sexual intercourse

Corresponding author:

Mahboobe Gholami

E-mail: gholamim1@nums.ac.com 


\section{INTRODUCTION}

Sexual activity in humans, when instinctive, is vital and incorporates the religious, mystical and historical concepts and themes (1). Sexual function results from cofunctioning of the neurological, vascular, and endocrine system (2). Sexual function depends on the family, social, and religious beliefs and is affected by gender, health, and personal experience (3). Sexual dysfunction is defined as a disorder in the sexual response cycle or pain during sex (2). Sexual dysfunction may be due to psychological and physical factors. In cases where the cause of sexual problems is physical, psychological factors may have a secondary role in complicated situations and can cause problems in sexual response and sexual dysfunction (4). Sexual activity is influenced by the person herself, family, community and culture, the complexity of the environment, her sexual history and her husband, past relationships, mental health status, recent medical problems, and hormonal status (5). Studies have shown that sexual dysfunction is closely related to mental illness and divorce, as well as being nervous, having abdominal pains and backache, impotence, and even disability in performing everyday activities are the consequence of being dissatisfied with the sexual activities. The favorable sexual performance is a key factor in the consolidation of the family (6-11).

However, couples who have sexual dysfunction might be unaware of its impact on marital life and its role in poor communication, low self-confidence, and depression (12-15). Lewis showed that $40-45 \%$ of women have at least one of the steps in their sexual response (16). Sexual dysfunction is typical in most societies, with $30-50 \%$ of women in developed countries, whose sexual relationship is affected by this crucial issue (17). Considering the harmful effects of sexual dysfunction in women, the consequent complications in family life and the importance of prevention and treatment, this study was done to determine the factors affecting the sexual function of women of reproductive age.

\section{MATERIAL AND METHODS}

This cross-sectional study was done in 2014-2015. The study population involved married women with stable sexual activity (at least for the last four weeks) referred to the Women's Clinic of Hakim Neyshabur Hospital, Iran. Entry criteria included: being at the reproductive age, being married, having a continuous sexual activity during the past four weeks. The study also included women with a history of vaginal surgery, a his- tory of uterine surgery, vaginal or uterine anomalies, a history of mental illness, the use of psychotic and narcotic drugs, while premarital relationships were excluded from the study. One thousand women entered the study, and were examined according to their entry and exit. Each woman was then asked to read and complete a standard sexual questionnaire carefully. Meanwhile, for the convenience of the subjects, a female questioner conducted the study. A standard questionnaire for women's sexual function (FSFI) was used to collect data. The questionnaire reliability has been confirmed in previous studies (12). This questionnaire with 19 questions evaluates the sexual function of women in six independent areas: desire, mental stimulation, humidity, orgasm, sexual satisfaction, and pain. In terms of scoring, according to the designer, the questionnaire for each area was scored by adding the scores of questions in each field and multiplying it by the factor number. Since, the score of field question in the standard questionnaire for women's sexual function (FSFI) is not equal in each section, in order to equate the domains with each other, the scores from the questions of each domain were combined and then multiplied by the factor number. The assigned scores are as follows: 1 . vaginal zone (1-5); 2 . sexual stimulation area, 3. vaginal moisture, 4.orgasm, 5 . pain (0-5) and 6. sexual satisfaction (0 or 1-5). A zero score indicates that the person did not have sexual activity during the last four weeks. By adding the scores of the six domains, the total scores were obtained. In this way, the score is such that a higher score indicated a better sexual function. By equating the domains, the maximum score for each field was 6 and the full scale was 36. The minimum score for the sexual desire domain was 1.2, 0 for vaginal humidity, orgasm and pain, 0.8 for satisfaction; the total scale score was equal to 2 .

Data were analyzed using SPSS16 software, chisquare, and one-way analysis of variance.

\section{RESULTS}

The findings showed that the prevalence of sexual disorders was significantly related to the level of education, husband's employment status, family income, specific diseases, and husband's education ( $\mathrm{p}<$ 0.05) (Table 1).

In this study, 1,000 women of reproductive age were studied and classified as follows: $39.5 \%$ had sexual dysfunction disorder, $37.5 \%$ had mild sexual dysfunction disorder, and $2 \%$ had a severe type of sexual disorder. Among the participants, the following disorders 
were found: orgasmic disorder $(12.7 \%)$, stimulation disorder $(8.7 \%)$, libido disorder $(7.1 \%)$, vaginal humidity disorder (5.5\%), and sexual pain dysfunction (3.1\%). The mean age in women participating in the study was $28.3 \pm$
4.56 years (45-17 years of age), and the mean age of their spouses was $33.1 \pm 7.30$ years (21-49 years of age) (Table2).

Table 1. The distribution of frequency of sexual activity disorder in research units according to the variables studied

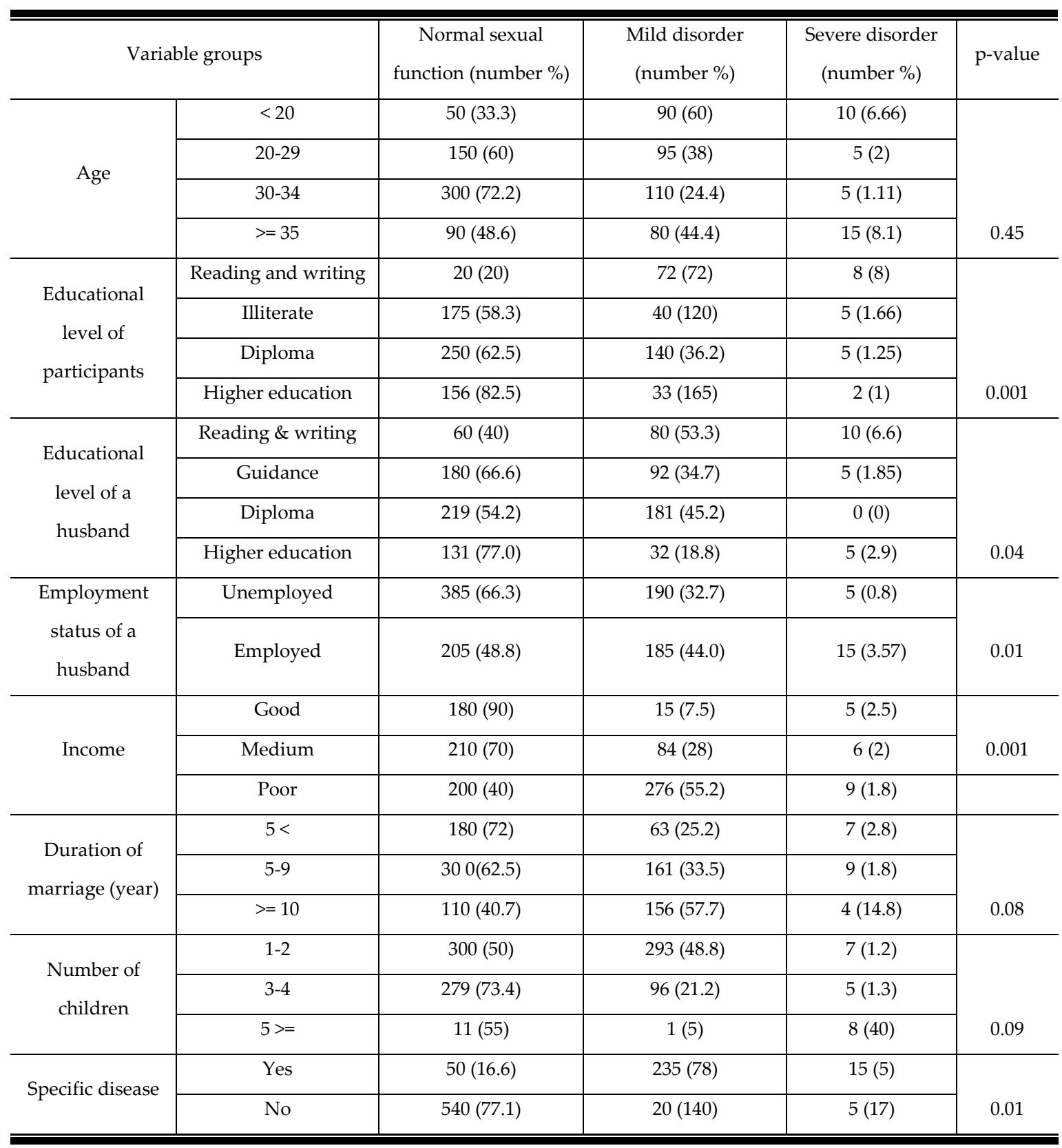


Table 2. Frequency distribution of the units under study in different areas of sexual activity

\begin{tabular}{l|c|c|c}
\hline \hline \multicolumn{1}{c|}{ Sexual activity } & $\begin{array}{c}\text { Normal } \\
\text { (number \%) }\end{array}$ & $\begin{array}{c}\text { Mild disorder } \\
\text { (number \%) }\end{array}$ & $\begin{array}{c}\text { Severe disorder } \\
\text { (number \%) }\end{array}$ \\
\hline Tendency & $16(51.6)$ & $153(48.1)$ & $1(0.3)$ \\
\hline Stimulation & $19(59.7)$ & $109(34.3)$ & $19(6)$ \\
\hline Vaginal wetting & $28(88.1)$ & $20(6.3)$ & $18(5.7)$ \\
\hline Orgasm & $25(81.4)$ & $41(12.9)$ & $18(5.7)$ \\
\hline Dyspareunia & $25(80.2)$ & $25(7.9)$ & $38(11.9)$ \\
\hline Satisfaction & $28(88.7)$ & $36(11.3)$ & -- \\
\hline \multicolumn{1}{c}{ Total } & $25(80.8)$ & $42(13.2)$ & $19(6)$ \\
\hline \hline
\end{tabular}

\section{DISCUSSION}

The results of the present study indicate that orgasmic disorder, lubrication disorder, libido disorder, stimulation disorder, and sexual pain were highly prevalent.

In the study of Bacooee et al. in Babol (18), the highest prevalence was recorded for libido disorder, stimulation disorder, pain in sexual activity, orgasmic disorder, difficulty in vaginal wetting and disorder in sexual satisfaction. The reason for the difference between the results of the he Bacooee's study and the present study can be the difference in the age of the population. In Bacooee's study, most women were aged between 20-34 years, while in the present study, the distribution of women was almost the same in all age groups. Also, the difference in the geographical location, customs, and culture may impact the results (18).

In a study carried out in Austria, the prevalence of orgasmic disorders was 39\%, 35\% of stimulation disorder, $23 \%$ of sexual desire disorder and pain was present with $12.8 \%$ in sexual activity (19). The outcomes of the Hisasue's study confirm the findings of the present study.

The results of a study in Turkey showed that $48.3 \%$ of participants had a tendency to disorder, $35.9 \%$ had stimulation disorder, $42.7 \%$ had irregular orgasm, $40.9 \%$ had disorder in lubrication and $42.9 \%$ had pain in sexual activity (20), which is slightly different but to some extent confirms the results of the present study.

The results of this study showed that the prevalence of sexual dysfunction is higher in the age group under 20 and over 40 of age. In a study by Cayan et al. in Turkey, the prevalence of female sexual dysfunction in- creased from $22 \%$ in women aged $27-18$ to $66 \%$ in women aged 57-48, which could be due to the approaching menopause and the problems associated with certain diseases.

However, in the present study, women over 45 were not included in the study. In this study, with the increase in the level of education, the prevalence of sexual dysfunction decreased, which is similar to other studies (16). However, the prevalence of sexual dysfunction was not associated with her husband's education level. The sexual dysfunction in women whose husbands were unemployed was higher than in other women, but the highest rates of sexual dysfunction were found in the study of Bacooee in women whose husbands were working.

In the present study, the prevalence of sexual dysfunction in women with low-income levels was higher. The results of the Bacooee's study also confirm this conclusion. In addition, sexual dysfunction in women with chronic disease was significantly higher than in others. In the study of Bacooee, sexual dysfunction in women with chronic illness was more likely to indicate physical and psychological problems associated with chronic disease.

Hisanse et al. reject the association of physical and psychological problems with chronic disease (17). In the Ponholzer study, cardiovascular disease, diabetes, depresssion, and urinary tract disorder have been identified as the risk factors for sexual dysfunction (15).

\section{CONCLUSION}

Sexual disorders are prevalent in women of reproductive age, and the establishment of counseling and 
educational centers to identify these women and their needs in order to increase the quality of life seems necessary.

\section{Acknowledgments}

This article is the result of a project in psychology with the code of ethics committee approved by the
Neyshabur University of Medical Sciences NUMS. REC.1396.28 code.

\section{Conflict of interest}

There is no conflict of interest. 


\section{References}

1. Kohanzad sh. About the impotence of man.Tehran, Danesh Publishing, 2016: 18.

2. Smith RL, Gallicchio L, Flaws JA. Factors affecting sexual activity in midlife women: results from the Midlife Health Study. J Women's Health 2017; 26:103-8. https://doi.org/10.1089/jwh.2016.5881

3. Lee JT, Hu YL, Meston CM, et al. The Sexual Satisfaction Scale for Women (SSS-W): adaptation and validation of a traditional Chinese version in Taiwan. J Sex Marital Ther 2018 : 29:1-34.

4. Vital M, de Visme S, Hanf M, et al. Using the Female Sexual Function Index (FSFI) to evaluate sexual function in women with genital mutilation undergoing surgical reconstruction: a prospective pilot study. Eur J Obstet Gynecol Reprod Biol. 2016: 202:71-4.

https://doi.org/10.1016/j.ejogrb.2016.04.029

5. Nappi RE, Cucinella L. Advances in pharmacotherapy for treating female sexual dysfunction. Eur J Obstet Gynecol Reprod Biol 2015:13:16:875-87. https://doi.org/10.1517/14656566.2015.1020791

6. McCabe MP, Sharlip ID, Lewis R, et al. Incidence and prevalence of sexual dysfunction in women and men: a consensus statement from the Fourth International Consultation on Sexual Medicine 2015. J Sex Med 2016:13:144-52.

https://doi.org/10.1016/j.jsxm.2015.12.034

7. Nappi RE, Cucinella L. Advances in pharmacotherapy for treating female sexual dysfunction. Expert Opin Pharmacother 2015: 13 :875-87.

https://doi.org/10.1517/14656566.2015.1020791

8. Jones E. The early development of female sexuality Int J Psychol 2018 :17: 133-145.

https://doi.org/10.4324/9780429474675-10

9. Motta-Mena NV, Puts DA. Endocrinology of human female sexuality, mating, and reproductive behavior. Horm Behav 2017;91:19-35.

https://doi.org/10.1016/j.yhbeh.2016.11.012
10. Barton D, Joubert L. Psychosocial aspects of sexual disorders. Aust Fam Physician 2000: 29: 527-31.

11. Segraves RT. Emerging therapies for female sexual dysfunction. Expert Opin Emerg Drugs 2003: 8: 51522.

https://doi.org/10.1517/eoed.8.2.515.21142

12. Goldstein I. Female sexual arousal disorder: new insights. Int J Impot Res 2000: 12: 152-7. https://doi.org/10.1038/sj.ijir.3900596

13. Heiman JR. Sexual dysfunction: an overview of prevalence, etiological factors, and treatments. J Sex Res 2002: 39: 73-8.

https://doi.org/10.1080/00224490209552124

14. Sidi H, Puteh SE, Abdullah N, et al. The prevalence of sexual dysfunction and potential risk factors that may impair sexual function in Malaysian women. J Sex Med 2007; 4: 311-21. https://doi.org/10.1111/j.1743-6109.2006.00319.x

15. Ponholzer A, Roehlich M, Racz U, et al. Female sexual dysfunction in a healthy Austrian cohort: prevalence and risk factors. Eur Urol 2005: 47: 36675.

https://doi.org/10.1016/j.eururo.2004.10.005

16. Lewis RW, Fugl-Meyer KS, Corona G, et al. Definitions/Epidemiology/Risk Factors for Sexual Dysfunction. J Sex Med. 2010;7:1598-607. https://doi.org/10.1111/j.1743-6109.2010.01778.x

17. Sungur MZ, Gunduz A. A comparison of DSM-IVTR and DSM-5 definitions for sexual dysfunctions: critiques and challenges. J Sex Med 2014;11:364-73. https://doi.org/10.1111/jsm.12379

18. Bakouie $\mathrm{F}_{\text {, }}$ Omidvar $\mathrm{S}$, Admir N. F. Determining the frequency of sexual dysfunction in married women and some related factors in Babol city. J MUBABOL 2008: 9: 59-64.

19. Hisasue S, Kumamoto $Y$, Sato $Y$, et al. Prevalence of female sexual dysfunction symptom and its rela- 
tionship to quality of life: a Japanese female cohort study. Urology 2005: 65: 143-8.

https://doi.org/10.1016/j.urology.2004.08.003
20. Oksuz E, Malhan S. Prevalence and risk factors for female sexual dysfunction in Turkish women. J Urol 2006; 175: 654-8.

https://doi.org/10.1016/S0022-5347(05)00149-7 


\title{
Ispitivanje faktora koji utiču na seksualnu funkciju kod žena u reproduktivnom periodu koje su upućene na Kliniku za ženske bolesti Hakim Nejšabur 2015. godine u Iranu
}

\author{
Fatemeh Shamsabadi ${ }^{1}$, Zahra Kamali ${ }^{2}$, Mahboobeh Gholami ${ }^{3}$, Toktam Bayat ${ }^{1}$, Akram Poosti ${ }^{4}$, \\ Marzeiyeh Feizi ${ }^{5}$ \\ ${ }^{1}$ Studentski istraživački komitet, Univerzitet medicinskih nauka u Nejšaburu, Nejšabur, Iran \\ ${ }^{2}$ Departman za sestrinstvo, Fakultet za sestrinstvo i akušerstvo, Univerzitet medicinskih nauka u Mašhadu, \\ Mašhad, Iran \\ ${ }^{3}$ Doktorand na kliničkim naukama, Departman za sestrinstvo, Univerzitet medicinskih nauka u Nejšaburu, \\ Nejšabur, Iran \\ ${ }^{4}$ Univerzitet medicinskih nauka u Nejšaburu, Nejšabur, Iran \\ ${ }^{5}$ Klinički psiholog, Univerzitet medicinskih nauka u Nejšaburu, Nejšabur, Iran
}

\section{SAŽETAK}

Cilj ove studije bio je određivanje faktora koji utiču na seksualnu funkciju kod žena u reproduktivnom periodu, sa osvrtom na neželjene efekte seksualne disfunkcije kod žena i njene posledice na porodični život. Istraživanje je urađeno kao studija preseka u periodu 2014 - 2015 godine. Studija je uključila udate žene sa redovnom seksualnom aktivnošću (barem u periodu od poslednje četiri nedelje), koje su upućene u Kliniku za ženske bolesti Hakim Nejšebur u Iranu. Kriterijumi za uključivanje u studiju podrazumevali su da su ispitanice bile $u$ reproduktivnom periodu, da su bile udate $i$ da su imale redovnu seksualnu aktivnost $u$ periodu od poslednje četiri nedelje. Studija je takođe uključila i žene sa istorijom hirurgije genitalnog trakta, anomaliju materice, sa istorijom mentalnih bolesti, kao i žene koje su upotrebljavale psihoaktivne supstance i narkotike. Za prikupljanje podataka korišćen je standardni upitnik za ispitivanje seksualne funkcije kod žena. Podaci su analizirani pomoću sofvera SPSS16, hi skver testa i jednofaktorske analize varijanse.

Rezultati su pokazali da je prevalencija seksualne disfunkcije bila u značajnoj vezi sa obrazovanjem, radnim statusom supruga, porodičnim primanjima, specifičnim bolestima, kao i sa obrazovanjem supruga $(\mathrm{p}<$ 0,05). Štaviše, najveća prevalecija zabeležena je kod poremećaja orgazma, lubrikacije, libida, stimulacije, kao i kod seksualne disfunkcije.

Poremećaji seksualne funkcije značajno su prisutni kod žena u reproduktivnom periodu, te uvođenje centara za savetovanje i edukaciju u cilju identifikovanja ovih žena i njihovih potreba izgleda opravdano.

Ključne reči: seksualna disfunkcija, indeks seksualne funkcije žena, orgazam, lubrikacija, želja za seksom, seksualna stimulacija, bol u toku seksualnog odnosa 